\title{
Response to the article: Prevalence of and factors associated with frailty in elderly users of the Family Health Strategy
}

Tubarão, 21 May 2019.

To Renato Peixoto Veras

Editor, Revista Brasileira de Geriatria e Gerontologia (The Brazilian Journal of Geriatrics and Gerontology)

\section{Dear Editor,}

I write to share my considerations of the article Prevalence of and factors associated with frailty in elderly users of the Family Health Strategy, published on pages 704-714 of Volume 21, No6, of the Revista Brasileira de Geriatria e Gerontologia (The Brazilian Journal of Geriatrics and Gerontology).

The study provided evidence of a diversity of factors related to frailty in different contexts, both in daily life and in the physiological process of aging itself, as such factors may influence the autonomy and quality of life of the elderly.

Old age has been the main risk factor for the development of certain systemic comorbidities, and should be closely monitored to reduce hospitalizations and mortality, given that the Brazilian population aged over 60 increased significantly between $1940-2000$, and is estimated to grow by $917 \%$ by the decade of $2025^{1}$.

In the study, the main variables associated with frailty identified were: being divorced, separated, widowed or single; showing symptoms of depression; dependence in activities of daily living; being at nutritional risk and suffering from comorbidities.

The prevalence of frailty was $65.25 \%$, which is considered very high compared to other studies which found a low prevalence of frailty in the same studied population (the elderly aged over 60) in their results. ${ }^{2}$

Another important point to consider regarding the high frailty index observed is the application of the Tilburg Frailty Indicator (TFI) instrument. This method was used as it encompasses the three spheres that make up the syndrome - the physical, psychological and social states ${ }^{3}$. At the same time, it should be noted that some studies used other methods that also encompass these three spheres of the syndrome, such as the Edmonton Frailty Scale, and did not find such high frailty rates ${ }^{4}$.

With regard to the TFI, different factors have been used to improve accuracy in identifying frailty, based on the clinical perspective, geriatric evaluation and the accumulation of deficits ${ }^{5}$. Therefore, among these instruments, the TFI seems to be the most appropriate for the current concept of frailty ${ }^{6,7}$, and thus is considered the most suitable method for identifying frailty in Brazilian society. 
Moreover, the article in question demonstrates that the other independent variables related to the frailty syndrome, such as: the female gender; being over 80 years old; being illiterate; being single or unaccompanied; and having other related morbidities (depression) are in line with other recent studies ${ }^{8}$.

Based on the results described in the article, I agree with the conclusion of the authors that the theme presented will contribute to the development of the prevention of adversity among the elderly population, which is preponderant in reducing hospitalization and mortality rates.

Sincerely,

\section{Thiago Gonçalves Souza}

Universidade do Sul de Santa Catarina, Programa de Graduação em Medicina. Tubarão, Santa Catarina, Brasil.

thiago_goncalves_220@hotmail.com

\section{REFERENCES}

1. RAMOS, Luiz Roberto; VERAS, Renato P. and KALACHE, Alexandre.Envelhecimento populacional: uma realidade brasileira. Rev. Saúde Pública [online]. 1987, vol.21, n.3, pp.211-224. ISSN 0034-8910. http://dx.doi. org/10.1590/S0034-89101987000300006.

2. Carneiro JA, Cardoso RR, Durães MS, Guedes MCA, Santos FL, Costa FM, et al. Frailty in the elderly: prevalence and associated factors. Rev Bras Enferm, 2017;70(4):747-52. Doi: http://dx.doi.org/10.1590/0034-7167-2016-0633

3. Santiago LM, Luz LL, Mattos IE, Gobbens RJJ. Adaptação transcultural do instrumento Tilburg FrailtyIndicator (TFI) para a população brasileira. Cad. Saúde Pública, 2012; 28(9):1795-801. Doi: http://dx.doi.org/10.1590/S0102311X2012000900018

4. Cruz DT, Vieira MT, Bastos RR, Leite ICG. Fatores associados à fragilidade em uma população de idosos da comunidade. RevSaude Publica. 2017;51(106):1-13. Doi: http://dx.doi.org/10.11606/s1518-8787.2017051007098

5. Tribess S, Oliveira RJ. Síndrome da fragilidade biológica em idosos: revisão sistemática. RevSalud Pública [Internet]. 2011 [acesso em 28 Abr. 2019];13(5):853-64. Disponível em: https://www.scielosp.org/article/rsap/2011.v13n5/853-864/

6. Santiago LM, Luz LL, Mattos IE, Gobbens RJ, van Assen MA. Psychometric properties of the Brazilian version of the Tilburg frailty indicator (TFI). Arch Gerontol Geriatrics, 2013;57(1):39-45. Doi: 10.1016/j.archger.2013.03.001.

7. Gobbens RJJ, van Assen MALM. Frailty and its prediction of disability and health care utilization: the added value of interviews and physical measures following a self-report questionnaire. Arch Gerontol Geriatr, 2012 ;55(2):369-79. DOI: $10.1016 /$ j.archger.2012.04.008.

8. Pegorari, M., \& Tavares, D. (2014). Fatores associados à síndrome de fragilidade em idosos residentes em área urbana. Revista Latino-Americana De Enfermagem, 22(5), 874-882. https://doi.org/10.1590/0104-1169.0213.2493 